\title{
Learning-Oriented Leadership: Managers as Facilitators of Human Resource Development in Daily Work
}

\author{
Andreas Wallo, Linköping University, Sweden
}

\begin{abstract}
The aim of this article is to provide theoretical and empirical insights concerning the role of managers in facilitating their employees' learning and development at work. The empirical basis of the article is two case studies of industrial companies in which managers were interviewed and observed. The results indicate that managers use combinations of different activities (planned, partially planned and spontaneous) and roles (the supporter, the educator and the confronter) to facilitate learning in different situations. Depending on the combination of activities, roles and the learning to be facilitated, two types of learning-oriented leadership emerge. The main type, performance-oriented leadership, is intended to facilitate adaptive learning. The less prominent type, development-oriented leadership, is intended to facilitate developmental learning. By illustrating learning-oriented leadership in daily work, the findings contradict the romantic notion that leadership for learning is charismatic and transformational.
\end{abstract}

Key Words: HRD, learning-oriented leadership, managerial work, workplace learning

\section{Introduction}

In today's globalized world, favourable learning conditions are considered important not only for individuals but also for organizational efficiency, development and innovative capacity (Ellström, 2010; Illeris, 2011; Tynjälä, 2013). Thus, the workplace is no longer seen as a site only for production, but also as an environment where formal training and informal learning can be integrated (Ellström, 2001). For human resource development (HRD) researchers and practitioners, this focus on learning entails an interest in how environments that facilitate learning can be created (Fuller \& Unwin, 2011). In this respect, the support from managers has especially been highlighted as important for promoting and enhancing individual and collective learning (Eraut, 2011; Loon, Mee Lim, Heang Lee \& Lian Tam, 2012). Popular designations for this new leadership are transformational and transactional leadership (Bass, 2000; Loon et al., 2012), developmental leadership (Gilley, Shelton \& Gilley, 2011; Larsson et al., 2003), managers as teachers (Agashae \& Bratton, 2001), managers as facilitators of learning (Cohen, 2013; Ellinger \& Bostrom, 2002), managers as developers (Warhurst, 2013), and managers as coaches (Ladyshewsky, 2010).

However, these conceptualizations tell us little about whether and how managerial work and leadership practice have actually changed, what managers in organizations do to facilitate learning, or what kind of learning is supposedly facilitated. Studies have indicated a need for empirically based research on the manager's role in facilitating learning processes (Döös, Johansson \& Wilhelmson, 2015; Ellström, 2012; Ellinger \& Bostrom, 2002; Hughes, 2004). The intended contribution of this article to HRD research and practice is to address this paucity 
of empirical data by presenting and discussing findings from case studies of two industrial companies in the light of previous research on learning-oriented leadership. More precisely, the article aims to further integrate the literature on leadership and learning and to provide theoretical and empirical insights concerning the manager's role in facilitating learning and development at work. The focus of the article is managers' views on learning and what managers do to facilitate their employees' learning in daily work.

In the article, leadership is understood as an interactive and reciprocal process through which a manager influences one or more employees to attain a goal (cf. Yukl, 2012). The process of leadership is situated within, and contingent on, contextual structures that may enable or constrain the interaction between manager and employees, but in turn, this interaction may either reproduce or transform these structures (cf. Archer, 1995; Hersey \& Blanchard, 1969). The focus on learning does not imply an emphasis only on formal training activities (e.g., courses). Rather, it implies a view of learning mediated by individual actions and interactions in different work situations and tasks, which is typically called informal learning (Ellström, 2011). As used here, informal learning refers to learning that occurs regularly in work as well as in everyday life, but is subordinate to other activities (e.g., work practices) that do not have learning as their primary goal. Such learning may occur without the awareness or intention to learn (implicit learning), or it may involve a more or less deliberate effort to learn (cf. Eraut, 2000; Marsick \& Watkins, 1990).

\section{Problematizing Leadership and Learning at Work}

As mentioned above, the management and HRD literature offer a plethora of conceptualizations for a leadership that is aimed at facilitating learning. In order to summarize the contribution to the understanding of learning-oriented leadership that is made by previous research, this section comprises a brief review of two leadership research approaches that have chosen different paths towards finding explanations and interpretations for this form of leadership. The review is then followed by a discussion of how theories of leadership and learning at work can be further intertwined.

\section{The normative approach}

The normative approach focuses on developing knowledge of how leadership should be performed to maximize effectiveness. Theories within this approach draw on classical models of effective leadership styles, especially the distinction between production-oriented and relationoriented leadership (cf. Blake \& Mouton, 1964; Likert, 1961). Among the theories concerning this approach, Bass's (2000) theory of transformational and transactional leadership, also known as the Full-Range Theory of Leadership, is probably the most popular (Yukl, 2012). Transformational leadership behaviours, i.e. individualized consideration, idealized influence, intellectual stimulation and inspirational motivation, are seen as the means to create a 'Learning Organization' using grand visions and charisma to lead employees to excellence (Bass, 2000). The Bass model also includes transactional behaviours, i.e. contingent reward and management by exception, but these behaviours are typically seen as a 'necessary evil' related to conventional leadership (cf. Larsson et al., 2003).

Few empirical studies have used Bass's model to explicitly focus on learning and development issues. In general, these studies use questionnaires and survey data to examine the occurrence 
of transformational leadership and its correlations with learning and organizational performance (cf. Raes et al., 2013; Loon et al., 2012; Thuy Pham \& Swierczek, 2006). In line with Bass's model, these studies find that transformational behaviours are positively linked to learning and innovation, whereas transactional behaviours are not (Amitay, Popper \& Lipshitz, 2005; Jung, Chow \& Wu, 2003). However, Vera and Crossan (2004) argue that transactional leadership may be more beneficial for learning than transformational leadership, depending on contingencies such as the external and internal environment, prior organizational performance, and stages of organizational life.

\section{The descriptive approach}

The descriptive approach stems from a critique of the normative agenda in research on effective leadership. Instead of focusing on what the manager should do, this approach examines what managers actually do and why they do it (Hales, 1986; 1999). Typically, the studies within this approach utilize qualitative data generated by observations and interviews (Tengblad, 2012). The results indicated that leadership is best understood not as a rational and proactive process but rather as a chain of reactive improvisations in a fragmented work context (Carlson, 1951; Mintzberg, 1973; Tengblad, 2012). These improvised actions by managers are interpreted as deliberate or 'intelligent' in the sense that the manager chooses when and how to react to influence the course of events in the organization in a desirable direction (Hultman, 2008; Kotter, 1999).

Studies of managers' work with the facilitation of learning have usually focused on roles or activities. The findings suggest that behaviours related to facilitative leadership include support before, during and after the learning activity, adding resources for learning, putting issues on the agenda, and creating a learning climate (cf. Coetzer, 2006; Döös et al., 2015; Ellinger \& Bostrom, 2002; Ellström, 2012). Studies have also focused on a more demanding form of leadership that requires employees to reflect on their daily work performance (Beattie, 2006; Ellinger \& Bostrom, 2002; Whittaker \& Marchington, 2003; Warhurst, 2013). Other results contradict the notion of a new, transformational paradigm, showing that managers' influence on learning occurs indirectly and by means of traditional leadership activities (Döös et al., 2015; Hughes, 2004; Viitala, 2004). According to Alvesson \& Sveningsson (2003), the actual performance of leadership tasks appears to be mundane in comparison to the notions of charismatic and heroic managers that characterize the modern, normative, theories of leadership. Accounts of 'doing leadership' are often related to micro-management, a term with negative connotations because it implies a hands-on style of leadership that fits poorly with the transformational ideal (Alvesson \& Sveningsson, 2003).

\section{Leadership for learning at work}

Although the two research approaches reviewed above contribute to an understanding of leadership that aims to facilitate learning, it is evident that that the actual relationship between the concepts of leadership and learning has not received much empirical focus (Matsuo, 2012). Furthermore, it is clear that learning, in most studies, is treated as unproblematic and as something of a 'black box'. This study argues that it is necessary to specify distinctions between different types of learning to gain comprehensive knowledge on the subject. There are many ways of conceptualizing different types of learning, but this article draws mainly on Ellström's (2006; 2011) distinction between the logic of performance and the logic of development, which in 
turn is based on March's (1991) theory of exploitation and exploration. The dominant theory of the logic of performance focuses on routine action obtained through 'adaptive learning', where rules and instructions are followed for known problems or situations. According to the logic of performance, learning is primarily instrumental and is valued when it promotes effective action, leading to a learning environment characterized by security, standardization, exploitation and consensus. The logic of development, in contrast, is characterized by the opposite pattern of activity, and focuses on reflective and alternative thinking, risk taking, critical reflection and the desire to experiment. Uncertainty and divergence are seen as potential generators of exploration and 'developmental learning' rather than as threats or inconveniences.

According to Ellström (2006; 2011), however, these logics and types of learning must not be seen as mutually exclusive, but rather as co-existing and complementary. Whereas Bass (2000) privileges transformational leadership over transactional leadership to facilitate learning, other studies focus on the organizational leadership challenge of finding a balance between exploitation/exploration, adaptation/development and transformation/transaction (Jansen, Vera \& Crossan, 2009; March \& Weil, 2005). However, finding this balance may be very difficult because one type of logic tends to dominate (Holmqvist, 2009). Moreover, empirical research on the specific ways that managers influence both types of learning is scarce (Jansen et al., 2009; Nemanich \& Vera, 2009).

\section{Research Approach and Methods}

The empirical foundation of this article consists of case studies of two Swedish industrial manufacturing companies. In the article they will be referred to as Company A and Company B. Company A offers solutions for the production and development of electronic and mechanical products. The company has approximately 145 employees in a factory in Sweden. Company B belongs to a global industrial group and offers solutions in the area of material handling. The main production facility in Sweden has approximately 1,000 employees. In total, the group has approximately 9,000 employees worldwide. These two companies operate in a market that exerts a high degree of change pressure on its actors and stakeholders. Both companies have been influenced by new philosophies on how to organize production. For instance, they have implemented lean production principles and methods aimed at strengthening performance and becoming a learning organization, such as waste elimination, just-in-time production, 5S, continuous improvement and reflection by 'Hansei' and 'Kaizen' (Liker, 2004; Liker \& Meier, 2006).

The data consisted of 41 interviews with 30 managers at different levels in the two companies, observations of 11 managers, and analysis of company documents (the 11 observed managers were interviewed twice).

Twelve individuals worked in managerial positions at Company A and they were all included in the study. Three of these managers worked at a higher organizational level (top management), and the other nine worked at a lower level in the organization (middle and line management). Nine were men and three were women, and they had an average age of 37 . Their average period of employment in the company was seven years, and they had an average of approximately three and a half years of managerial experience within the company. The highest education level of eight of the managers was upper secondary school. Four of the managers had a universitylevel education. Of these 12 managers, five were also selected to participate in the observation 
study. The selection criteria were established so that a variety of different departments would be represented in the study. At Company B, it was not possible to include all managers in the company. Instead, the study included the production of a specific product model and managers who were in some way connected to this production process. To match the selection from Company A, this study included managers in the production departments and in non-production departments (i.e., the planning department and the Human Resources department). Eighteen managers from Company B were selected to participate in the study. Six of these managers belonged to a higher hierarchical level (top management), and 12 belonged to a lower hierarchical level (middle and line management). Sixteen of the managers were men and two were women, and their average age was 37 . The average managerial experience within the company was approximately three years, and their average period of employment was eight and a half years. The highest educational level of 10 of the managers was upper secondary school, and eight of the managers had a technical university education. Six of the selected managers were also included in the observation study. As in the case of Company A, the selection criteria were established to include different functions of the organization in the study.

The interviews were based on a semi-structured interview guide that included the following areas and themes:

- Personal background in leadership (e.g., education, previous employment, leadership experience, and reasons for becoming a manager).

- Work as a manager (What they do. Why these tasks? How much and with whom?).

- Models/good leadership (What is good leadership? Is it possible to live up to demands and expectations?).

- Notions and experiences of learning and development in organizations.

- Notions and experiences of the manager's role in relation to employees' learning and development at work.

The interviews were conducted during the managers' regular work hours, on the companies' premises and in places that ensured privacy. The length of the interviews varied from one hour and 15 minutes to two hours. The interviews were recorded and transcribed verbatim.

The observations took place over one and a half weeks in each company, and the 11 managers were observed for one working day each. The observations can be characterized as broad and holistic (Wolcott, 1999) because they included the daily work practices of the managers, ranging from coffee breaks to events specifically oriented towards learning and development. Data were recorded in a notebook and subsequently transcribed using a computer. The observed managers were interviewed following the observation. The purpose of these interviews was partly to collect evaluation feedback (Patton, 2002) and partly to identify critical incidents (cf. Ellinger \& Bostrom, 2002) concerning learning and development.

The document study included internal documents on organization, leadership, learning and development, which were provided by the company's top management, the Human Resource (HR) department and the participating managers.

The analysis of the data took place in three steps. In the first step, the transcripts were read and descriptive codes were used to obtain an overall idea of the content of each interview. In 
the second step, a provisional 'starting list' of factors and conditions that might be useful for organizing the collected data was created. This list comprised parts of a conceptual framework for learning and leadership (e.g., previous research relevant for managing the data). Miles, Huberman and Saldaña (2014) refer to this step as creating codes. In the third step, the findings from the first two steps were discussed in an attempt to reach a broader understanding of the data in relation to the research questions and previous research. The two cases were initially analysed and written separately, and then, a cross-case analysis was conducted to identify common themes in both cases (Miles et al., 2014). This article presents the results of the cross-case analysis.

In addition, the empirical material has also been presented in a series of seminars with both case organizations. The aim of these seminars was to create opportunities for joint analysis of the findings and a critical and reflective learning process for both researchers and practitioners (cf. Argyris \& Schön, 1989; Sandberg \& Wallo, 2013). In this step, representatives from the companies validated the findings, but also helped the researchers to develop the analysis by providing alternative perspectives and insights. According to the practitioners, the seminars provided new knowledge that supported leadership development in both companies.

\section{Results}

The next section describes the interviewed managers' views on learning and how they, in terms of their activities and roles, manage issues of learning and development in daily work.

\section{The managers'views on learning}

The results of the interviews and observations show that learning and development are perceived as necessary to keep up with the competition, and the respondents describe these concepts in positive terms. Furthermore, the managers relate the concept of learning to formal competence development and perceive it as something that occurs separately from daily production, such as courses and training activities inside or outside the organization.

Learning and development for me is that they get to go to the courses they need in order to do their job properly. (Company B, IP13)

Managers with this view of learning often perceive the actual time for facilitating employees' learning and development as limited. In contrast, a few responses indicate a view of learning as an ongoing process embedded in daily work. This view of learning is often related to lean production methods, such as continuous improvements, but the managers also describe it as more generally connected to the ability to learn from your own mistakes.

... sometimes you make mistakes and take a hit, but then you learn from it. It's an experience and when you're learning, you develop. Not just to do better at work, but for life really. (Company A, IP1)

\section{The managers'activities}

The activities that the managers use to facilitate learning and development can be categorized depending on their degree of formalization. There is evidence of three types of activities: planned activities, partially planned activities and spontaneous activities. 
Planned activities are connected to formalized and official systems for development within companies. These activities include various formal interventions for employees' competence development, such as shorter courses and long-term training programmes. Planned activities also include dialogues for development between the manager and individual employees, such as performance reviews and salary discussions. These dialogues are important because they offer designated times to talk about development issues that are rarely part of daily discussions. However, the dialogues are also problematic because they are time-consuming and tend to focus on social rather than developmental issues. Planned activities also include actions and procedures related to the introduction of lean production principles. In particular, the managers speak of Kaizen, (i.e., continuous improvement) as important for the development of daily work tasks and routines. Company B uses a Kaizen activity called Improvement Groups:

Well, we have to stimulate them with something, and then we came up with the Improvement Groups. There was a lot of energy not being taken advantage of because everything was about learning the station as fast as possible, and even if there were plenty of good ideas, there was no space or forum to deal with them. (Company B, IP7)

The partially planned activities are less formal but are organized and connected to HR structures. These activities include discussing issues such as employment contracts, work descriptions and systems for training and development, and involve making changes to positions and tasks by giving employees new assignments or increased responsibilities. For instance, at Company B, becoming a coordinator is described as an important development step in the internal career structure of the departments. Partially planned activities also include opportunities for knowledge sharing between employees. For example, experienced and skilled workers may be paired with newcomers, or meetings may be arranged to promote knowledge sharing and reflection on daily work operations. A manager at Company A describes such a meeting:

I divide them into groups of four and they start building different cables, and then there are lots of things in the design that they didn't know about. So many things pop up, and every time, someone stands up and says that it's amazing. We sit so close to each other but still there are so many differences between the jobs. (Company A, IP7)

The spontaneous activities are not easily described. Sometimes they are impromptu actions in daily work, whereas at other times they are discussed beforehand. The spontaneous activities occur frequently during the workday, but they are not always recognized as a source of learning and development for the employees. The first category of these activities centres on daily problem-solving processes in the companies, where the manager works with the employees to help them learn from the problem at hand and find solutions independently, without waiting for direction.

... sometimes I wonder why they don't ask themselves "Why does this problem occur week after week?" But instead of coming up with a suggestion, they take the problem to me. (Company A, IP3)

The second category involves improvised educational interventions, where the managers engage in teaching activities to explain certain procedures and to encourage reflection on the daily work. An improvised educational intervention is described in the following quote:

So, basically, for the following six months I spent almost all my time in the shop, talking about the new concepts. And when there were questions or ideas I dealt with them right away, on the spot, instead of waiting for a weekly meeting. I tried to explain pedagogically when someone said, "What do we need this damn Kanban for?" (Company B, IP18) 
Of the three types of activities, the managers refer most often to planned activities. The data also reveal that Company B had worked more with lean production than Company A.

\section{The managers' roles}

The data show that the managers act in different ways when working with the activities described above. In the empirical material, three main roles or sets of behaviours are discernible. These roles are called the supporter, the educator and the confronter roles.

The manager as a supporter aims to create a secure and tolerant environment where it is acceptable to fail as long as employees try to learn from their mistakes. The manager does not judge too quickly or rush to make decisions. It is important that the employees are 'on board' with decisions that concern their work and that their ideas for development are encouraged. The supporter tries to motivate the hesitant employee and to gently slow down the overly enthusiastic. The supporter role is illustrated in the following quote:

I use positive encouragement: "You can do it; if you want to, you will be able to!" You know, constantly cheering them on. (Company A, IP3)

The manager as an educator aims to create possibilities for learning by actively engaging in the process. For simple procedures, this role involves instructing employees on how to complete tasks, and for more complex processes, such as implementing new production principles, the manager uses pedagogical skills to teach employees. The educator is concerned with finding new and innovative ways to solve old problems and with creating situations where the employees need to think outside the box and apply new perspectives. For example, the educator illustrates a problem on the whiteboard, tries to divide it into smaller parts, or asks tricky questions that encourage the employees to reflect on their daily work. The following quote illustrates the educator role:

... it was a bit funny because when they came to me they said, "Oh, you ask so many strange questions". I saw the entire thing from my perspective, which I'm used to, but I noticed that they appreciated it and that it made them think that, well, "I guess that's another way of seeing it". (Company B, IP11)

The manager as confronter takes a somewhat stronger approach to the employees' learning and development by demanding change and commitment. The confronter does not back down or allow the employee to give up. Instead of avoiding potential conflict, the confronter dives in and immediately takes control of the discussion. Acting as a confronter also involves acting professionally and avoiding anger, which clouds judgement and affects the manager's relationship with the employees. In some cases, however, when no other solution can be found or when an employee is actively working against the good of the department, the manager must play an active role. The following quote from Company A illustrates the confronter role:

Instead, I tried to get him to some kind of realization, to understand that I was serious, "You can't go on like this". And that's a leader thing as well. In order to get an individual to change you may almost have to push him over the edge before things start shaking. And that's very dependent on what kind of person you are; some have to come really close to the edge before anything happens. (Company A, IP5)

These three roles are evident in the empirical material, regardless of company or hierarchical level. Furthermore, these roles can be seen as complementary because the managers combined or alternated roles depending on the type of activity, or on situational or contextual factors, such as 
the attitudes of the employees, financial resources, support from top management, and external change pressure.

\section{Discussion}

As the results have shown, the managers often speak of planned activities when addressing employees' learning and development. However, the results also show that managers use activities of a more spontaneous character to facilitate learning and development. In other words, they make use of problems that arise during the workday to create possibilities for learning (cf. Kotter, 1999). These findings suggest that managers are more than 'puppets on a string' who merely react to struggles; rather, their techniques, while not always proactive and planned, may be seen as intelligent improvisations (cf. Hultman, 2008).

Furthermore, the results show that the planned, partially planned, and spontaneous activities used to facilitate learning and reflection are, in fact, quite ordinary (cf. Alvesson \& Sveningsson, 2003; Hughes, 2004; Viitala, 2004). They are not extraordinary interventions performed by charismatic leaders, as suggested by proponents of models for effective leadership (Bass, 2000).

Let us take a closer look at the previously presented roles of supporter, educator and confronter in the light of previous leadership research. Regarding the supporter role, it is possible to see similar patterns in studies within the descriptive approach and the normative leadership approach. Several studies describe leadership as oriented towards encouragement, caring and support (Bass, 2000; Beattie, 2006; Ellinger \& Bostrom, 1999). The educator role is also found in previous studies. For example, the manager is described as trying to clarify and simplify problems for employees and as trying to widen the perspectives of employees to allow them to see their work in a different way (Beattie, 2006; Ellinger \& Bostrom, 1999). The educator role also bears resemblances to the so-called 'Sensei' (teacher) in lean production (Liker \& Meier, 2006). Unlike the supporter and the educator, which are associated with softer leadership, the confronter role stands out in this study. In previous research, this kind of leadership has typically been considered as less favourable for learning (Amitay et al., 2005; Bass, 2000) and thus has not been extensively discussed in relation to learning and development. However, the managers in both cases in this study did not view this role as less important than the supporter or educator roles. These results show that a confronting leadership need not be seen as innately negative in relation to employees' learning and development. Rather, setting boundaries and demanding reflection may help to initiate learning and development in some situations and contexts (cf. Beattie, 2006; Ellinger \& Bostrom, 2002; Whittaker \& Marchington, 2003; Vera \& Crossan, 2004; Warhurst, 2013).

Thus far, the roles and activities of the managers have been discussed in relation to previous leadership research. However, we have not yet examined the connections between the managers' views of learning, roles and activities, on the one hand, and the type of learning outcome, on the other. Based on the distinction between adaptive and developmental learning (Ellström, 2006) and the ideal typical orientations of leadership (cf. Bass, 2000; March \& Weil, 2005), it is possible to distinguish two patterns of learning-oriented leadership: performance-oriented leadership and development-oriented leadership.

Performance-oriented leadership understands learning as connected with formal education and used to reach production goals. It aims to improve workers' performance by building on their 
existing knowledge. All three leadership roles, i.e. supporter, educator and confronter, are used and combined depending on the situation (cf. Hersey \& Blanchard, 1969), but they are mainly oriented towards keeping things running smoothly. For instance, managers act supportively and make an effort to create a trusting relationship and a relaxed atmosphere where employees feel safe discussing their problems or their uncertainties regarding opportunities for learning (cf. Ellinger \& Bostrom, 1999; Ellström, 2006). Managers also act as educators by instructing employees on how to think or act and by explaining why the employees' learning is important for the performance of the company. In contrast, the confronter uses authority to control employees who are not 'in sync' with the organization. The focus of performance-oriented leadership activities is on standardized and planned activities, with some elements of partially planned activities. For example, formal education is used to maintain employees' competence, and development dialogues concentrate on the competencies that employees need to improve their current performance. Furthermore, increased salary is used as a contingent reward (Bass, 2000) to ensure that employees continue to make progress. Similarly, evidence suggests that partially planned activities may be used to facilitate adaptive learning. Job rotation presents opportunities to expand workers' horizons by allowing them to work in other sectors of the company where assignments are similar to their ordinary tasks. Spontaneous activities, in contrast, are considered to be annoying disturbances and evidence of micro-management rather than opportunities for learning (cf. Alvesson \& Sveningsson, 2003).

The second and somewhat less pronounced pattern, development-oriented leadership, relates to a broader view of learning. In addition to courses and other types of formal education, managers accentuate learning that occurs during the workday (cf. Eraut, 2000; Marsick \& Watkins, 1990). To facilitate developmental learning (Ellström, 2006), the manager aims to expand the employees' current knowledge by contributing new perspectives. Like performance-oriented leadership, development-oriented leadership makes use of the three roles by alternating between them, depending on the situation (cf. Hersey \& Blanchard, 1969). In relation to development, the supporter encourages the employees to explore new possibilities and innovative ways of working. The educator focuses on challenging the employees by asking tricky questions to stimulate the learning process and initiate reflection. The confronter also challenges employees but does so by using a tougher approach. The confronter forces employees out of their comfort zones to confront their problems. Concerning the activities used, the emphasis is on partially planned and spontaneous activities in daily work. For example, developmental learning is essential for an employee to receive new assignments or to take on a new position in which his or her previous competence may be insufficient. In daily problem-solving processes for developmental learning, the aim is for employees to question the nature of problems and to attempt to discover their causes instead of identifying short-term solutions. Similarly, improvised educational interventions may facilitate developmental learning by encouraging critical reflection on the daily work process and new production procedures and principles.

In Table 1, the two types of learning-oriented leadership are summarized in terms of the managers' views of learning, what they do (their activities), and how they act (their roles). A performance orientation may create possibilities for learning that are primarily adaptive in character, whereas a development-oriented leadership may facilitate developmental learning. 


\begin{tabular}{lll}
\hline & Performance-oriented leadership & Development-oriented leadership \\
\hline $\begin{array}{l}\text { The manager's } \\
\text { view of learning }\end{array}$ & $\begin{array}{l}\text { Formal and organized - connected } \\
\text { with education and courses }\end{array}$ & $\begin{array}{l}\text { Informal and continuous - connected } \\
\text { with everyday work }\end{array}$ \\
$\begin{array}{l}\text { Managerial } \\
\text { activities }\end{array}$ & $\begin{array}{l}\text { Emphasis on planned activities with } \\
\text { elements of partially planned activities }\end{array}$ & $\begin{array}{l}\text { Emphasis on partially planned activities } \\
\text { and spontaneous activities }\end{array}$ \\
$\begin{array}{l}\text { Managerial roles } \\
\text { - The supporter }\end{array}$ & - Reassures and comforts & - Encourages and inspires \\
- The educator & - Instructs and trains & - Stimulates analysis and critical reflection \\
- The confronter & - Controls and sets boundaries & - Challenges and problematizes \\
$\begin{array}{l}\text { Type of learning } \\
\text { supported }\end{array}$ & $\begin{array}{l}\text { Adaptive learning (e.g. mastering of } \\
\text { procedures and routines) }\end{array}$ & $\begin{array}{l}\text { Developmental learning (e.g. developing } \\
\text { innovative and creative solutions) }\end{array}$ \\
\hline
\end{tabular}

Table 1: Two Types of Learning-oriented Leadership

Taken together, the results indicate that it is possible to discern learning-oriented leadership in both cases, but with a focus on performance and adaptive learning. However, neither of the managers are extreme cases in that they are focused only on performance. Furthermore, the facilitation of critical reflection, an important prerequisite for developmental learning (Ellström, 2006), is not common in either case.

\section{Conclusions and Implications}

This article set out to make a contribution to HRD research and practice by providing theoretical and empirical insights concerning the manager's role in facilitating learning and development at work. Based on the empirical material presented in the article it is possible to draw at least three conclusions. The first conclusion is that it is far too simplistic to integrate learning and leadership research by claiming that transformational leadership is good for learning, whereas transactional leadership is not. By problematizing the concept of learning and distinguishing between developmental learning/exploration and adaptive learning/exploitation (Ellström, 2001; March, 1991), the picture becomes much more nuanced and complex. The confronter role, like transactional leadership, can be seen to be just as important for facilitating learning (Vera \& Crossan, 2004) as the supporter role and the educator role, both of which are more closely related to transformational leadership.

The second conclusion is that learning-oriented leadership is sensitive to contextual factors. Depending on the situation, the evidence suggests that managers can 'ambidextrously' (Holmqvist, 2009; Nemanich \& Vera, 2009) alternate between different roles and use many different types of activities to facilitate learning and to balance between developmental learning/ exploration and adaptive learning/exploitation. The two types of learning-oriented leadership thus build on established theories of situational/contingency leadership (Hersey \& Blanchard, 1969). Unfortunately, this situational approach is somewhat downplayed in Bass's (2000) universalistic model.

The third conclusion is that the activities and roles that emerge in the two cases seem far from the extraordinary and charismatic image that currently dominates leadership research. Thus, it can be concluded that managers can conduct learning-oriented leadership using ordinary activities 
and behaviours that occur naturally in the hectic and fragmented context of daily work and that hold a large capacity for informal learning (Alvesson \& Sveningsson, 2003; Döös et al., 2015; Hughes, 2004; Viitala, 2004).

Numerous interesting opportunities for future study exist within this research stream. A limitation of the present study is that it is based on case studies of two industrial companies. Thus it would be relevant for further studies to examine the combinations of activities and leadership roles in different contexts and using other research methods. Another interesting research area would be to approach learning-oriented leadership from an employee perspective to identify what types of 'employeeship' may be facilitative of learning.

One practical implication of this study is to highlight the importance of balancing the organization's logic of development and logic of performance to achieve a leadership that truly facilitates both adaptive and developmental learning. As indicated above, such a balancing act does not occur spontaneously. Rather, there is a need for organizations and their managers to create opportunities and support for increased developmental learning at work. In relation to this, an issue that may be given some extra attention by practitioners is how to organize for critical reflection in the daily work, which is a key component of developmental learning (Ellström, 2006). In this regard, some of the principles and methods associated with lean production, e.g. Kaizen or Hansei, may be useful.

\section{References}

Agashae, Z., \& Bratton, J. (2001). Leader-follower dynamics: Developing a learning environment. Journal of Workplace Learning, 13(3), 89-103.

Alvesson, M., \& Sveningsson, S. (2003). Good visions, bad micro-management and ugly ambiguity: contradictions of (non-) leadership in a knowledge-intensive organization. Organization Studies, 24(6), 961-988.

Amitay, M., Popper, M., \& Lipshitz, R. (2005). Leadership styles and organizational learning in community clinics. The Learning Organization, 12(1), 57-70.

Archer, M. S. (1995). Realist social theory: the morphogenetic approach. Cambridge: Cambridge University Press.

Argyris, C., \& Schön, D. A. (1989). Participatory Action Research and Action Science Compared. The American Behavioral Scientist, 32(5), 612-623.

Bass, B. M. (2000). The future of leadership in learning organizations. Journal of Leadership \& Organizational Studies, 7(3), 18-40.

Beattie, R. S. (2006). Line managers and workplace learning: Learning from the voluntary sector. Human Resource Development International, 9(1), 99-119.

Blake, R. R., \& Mouton, J. S. (1964). The managerial grid. Houston, TX: Gulf Publishing Company.

Carlson, S. (1951). Executive Behaviour. A study of the workload and the working methods of managing directors. Stockholm: C.A. Strömbergs.

Coetzer, A. (2006). Managers as learning facilitators in small manufacturing firms. Journal of Small Business and Enterprise Development, 13(3), 351-362.

Cohen, J. (2013). The nature of learning being facilitated by frontline managers. Human Resource Development International, 16(5), 502-518.

Döös, M., Johansson, P., \& Wilhelmson, L. (2015). Beyond being present: Learning-oriented leadership in the daily work of middle managers. Journal of Workplace Learning, 27(6), 408-425.

Ellinger, A. D., \& Bostrom, R. P. (1999). Managerial coaching behaviors in learning organizations. Journal of Management Development, 18(9), 752-771. 
Ellinger, A. D., \& Bostrom, R. P. (2002). An examination of managers' beliefs about their roles as facilitators of learning. Management Learning, 33(2), 147-179.

Ellström, E. (2012). Managerial support for learning at work: a qualitative study of first-line managers in elder care. Leadership in Health Services, 25(4), 273-287.

Ellström, P.-E. (2001). Integrating learning and work: Problems and prospects. Human Resource Development Quarterly, 12(4), 421-435.

Ellström, P.-E. (2006). Two logics of learning. In. E. Antonacopoulou, P. Jarvis, V. Andersen, B. Elkjaer, \& S. Høyrup. (Eds.), Learning, working and living: Mapping the terrain of working life learning (pp.33-49). Basingstoke: Palgrave Macmillan.

Ellström, P.-E. (2010). Organizational Learning. In P. Peterson., E. Baker., \& B. McGaw. (Eds.), International Encyclopaedia of Education, volume 1 (pp.47-52). Oxford: Elsevier.

Ellström, P.-E. (2011). Informal Learning at Work: Conditions, Processes and Logics. In. M. Malloch, M., L. Cairns, K. Evans, \& B.N. O'Connor (Eds.), The SAGE Handbook of Workplace Learning (pp.105-119). Thousand Oaks, CA: SAGE Publications Inc.

Eraut, M. (2000). Non-formal learning and tacit knowledge in professional work. British Journal of Educational Psychology, 70(1), 113-136.

Eraut, M. (2011). How Researching Learning at Work Can Lead to Tools for Enhancing learning. In. M. Malloch, L. Cairns, K. Evans, \& B.N. O'Connor (red.). The SAGE Handbook of Workplace Learning (pp.181-197). Thousand Oaks, CA: SAGE Publications.

Fuller, A., \& and Unwin, L. (2011). Workplace Learning and the Organization. In. M. Malloch, M., L. Cairns, K. Evans, \& B.N. O'Connor (Eds.), The SAGE Handbook of Workplace Learning (pp.46-59). Thousand Oaks, CA: SAGE Publications Inc.

Gilley, J. W., Shelton, P. M., \& Gilley, A. (2011). Developmental Leadership A New Perspective for Human Resource Development. Advances in Developing Human Resources, 13(3), 386-405.

Hales, C. (1999). Why do managers do what they do? Reconciling evidence and theory in accounts of managerial work. British Journal of Management, 10(4), 335-350.

Hales, C. P. (1986). What do managers do? A critical review of the evidence. Journal of Management Studies, 23(1), 88-115.

Hersey, P., \& Blanchard, K. H. (1969). An introduction to situational leadership. Training and Development Journal, 23, 26-34.

Holmqvist, M. (2009). Complicating the organization: a new prescription for the learning organization? Management Learning, 40(3), 275-287.

Hughes, C. (2004). The supervisor's influence on workplace learning. Studies in Continuing Education, $26(2), 275-287$.

Hultman, G. (2008). Ambiguity as work. Teachers' knowledge creation in classrooms. New Zealand Journal of Teachers' Work, 5(1), 21-35.

Illeris, K. (2011). Workplaces and Learning. In. M. Malloch, M., L. Cairns, K. Evans, \& B.N. O'Connor (Eds.), The SAGE Handbook of Workplace Learning (pp.32-45). Thousand Oaks, CA: SAGE Publications Inc.

Jansen, J. J., Vera, D., \& Crossan, M. (2009). Strategic leadership for exploration and exploitation: The moderating role of environmental dynamism. The Leadership Quarterly, 20(1), 5-18.

Jung, D. I., Chow, C., \& Wu, A. (2003). The role of transformational leadership in enhancing organizational innovation: Hypotheses and some preliminary findings. The Leadership Quarterly, 14(4), 525-544.

Kotter, J. P. (1999). John P. Kotter On What Leaders Really Do. Boston, MA: Harvard Business School Press.

Ladyshewsky, R. K. (2010). The manager as coach as a driver of organizational development. Leadership \& Organization Development Journal, 31(4), 292-306.

Larsson, G., Carlstedt, L., Andersson, J., Andersson, L., Danielsson, E., Johansson, A., Johansson, E., Robertsson, I., \& Michel, P.-O. (2003). A comprehensive system for leader evaluation and development. Leadership \& Organization Development Journal, 24(1), 16-25.

Liker, J. K. (2004). The Toyota way: 14 management principles from the world's greatest manufacturer. New York, NY: McGraw-Hill. 
Liker, J. K., and Meier, D. (2006). The Toyota way fieldbook: a practical guide for implementing Toyota's $4 P s$. New York, NY: McGraw-Hill.

Likert, R. (1961). New Patterns of Management. New York, NY: McGraw-Hill.

Loon, M., Mee Lim, Y., Heang Lee, T., \& Lian Tam, C. (2012). Transformational leadership and job-related learning. Management Research Review, 35(3/4), 192-205.

March, J. G. (1991). Exploration and exploitation in organizational learning. Organization Science, 2(1), 71-87.

March, J. G., \& Weil, T. (2005). On leadership. Cambridge: Blackwell Publishing.

Marsick, V. J., \& Watkins, K. (1990). Informal and incremental learning in the workplace. London and New York: Routledge.

Matsuo, M. (2012). Leadership of learning and reflective practice: An exploratory study of nursing managers. Management Learning, 43(5), 609-623.

Miles, M. B., Huberman, A. M., \& Saldaña, J. (2014). Qualitative data analysis: a methods sourcebook. (3 ed.). Los Angeles: Sage.

Mintzberg, H. (1973). The Nature of Managerial Work. New York, NY: Harper \& Row.

Nemanich, L. A., \& Vera, D. (2009). Transformational leadership and ambidexterity in the context of an acquisition. The Leadership Quarterly, 20(1), 19-33.

Patton, M. Q. (2002). Qualitative Research and Evaluation Methods, 3rd ed. Thousand Oaks, CA: Sage Publications, Inc.

Raes, E., Decuyper, S., Lismont, B., Van den Bossche, P., Kyndt, E., Demeyere, S., \& Dochy, F. (2013). Facilitating team learning through transformational leadership. Instructional Science, 41(2), 287-305.

Sandberg, F., \& Wallo, A. (2013). The interactive researcher as a virtual participant: A Habermasian interpretation. Action research, 11(2), 194-212.

Tengblad, S. (2012). Conclusions and the way forward: Towards a practice theory of management. In S. Tengblad. (Ed.), The work of managers: Towards a practice theory of management (pp.337-356). New York, NY: Oxford University Press.

Thuy Pham, N., \& Swierczek, F. W. (2006). Facilitators of organizational learning in design. The Learning Organization, 13(2), 186-201.

Tynjälä, P. (2013). Toward a 3-P model of workplace learning: a literature review. Vocations and Learning, 6(1), 11-36.

Vera, D., \& Crossan, M. (2004). Strategic leadership and organizational learning. Academy of Management Review, 29(2), 222-240.

Viitala, R. (2004). Towards knowledge leadership. Leadership \& Organization Development Journal, 25(6), 528-544.

Warhurst, R. P. (2013). Learning in an age of cuts: managers as enablers of workplace learning. Journal of Workplace Learning, 25(1), 37-57.

Whittaker, S., \& Marchington, M. (2003). Devolving HR responsibility to the line: threat, opportunity or partnership? Employee Relations, 25(3), 245-261.

Wolcott, H. F. (1999). Ethnography: a way of seeing. Walnut Creek, CA: Altamira Press.

Yukl, G. (2012). Leadership in Organizations, 8th ed. Upper Saddle River, NJ: Prentice-Hall International, Inc.

\section{The Author}

Andreas Wallo is an Associate Professor in the Department of Behavioural Sciences and Learning at Linköping University. He is also affiliated with the HELIX Competence Centre at Linköping University. His research interests include leadership and managerial work in organizations, workplace learning, human resource development, human resource management, and interactive research. The results of his research have been published internationally in management and HRD academic journals, and also in national practitioner publications. He is currently a convenor for the ESREA (European Society for Research on the Education of Adults) Network on Working Life and Learning Research. 